\title{
AN ECONOMETRIC ANALYSIS ON DETERMINANTS OF FOREIGN DIRECT INVESTMENT IN TURKEY
}

\author{
Mikail PEHLIVAN ${ }^{1}$
}

\begin{abstract}
The globalization phenomenon, which started with financial liberalization in developed countries in the 1970s, was expanded in the 1980s and 90s by developing countries. This globalization process, which started with financial liberalization, made the countries more affected with each other.Foreign direct investments (FDI)are desired to be drawn into the country for the purposes of medium and long-term employment, technology transfer, integration into international markets, development of competitive environment and training of qualified labor force from developed countries to developing countries. In this study, it is aimed to describe the effect of some macroeconomic variables on FDI in Turkey in an econometrical point of view. In this analysis, for the period of 2007Q1-2018Q1, the effects of economic growth, trade openness, exchange rate, labor cost and environmental taxes on FDI are analyzed by using the Autoregressive Distributed Lag (ARDL). While economic growth and trade openness variables were expected positive on FDI; exchange rate, labor cost and environmental taxes variables were expected negative on FDI. As a result, it is found that the effect of economic growth, trade openness and environmental taxes on FDI were not statistically significant in long-term but, labor cost and exchange rate variables were statistically significant in long-term. In this context, effects of the labor cost and exchange rate on the FDI were found to be negative in the long-term. In addition, the results of Error Correction Model (ECM) reveal that the short-term deviations can be balanced in the long-term.
\end{abstract}

Keywords: Foreign Direct Investments, ARDL, Coingtegration, Error Correction Model

JEL Code: C22, F21, R11.

\section{Introduction}

The globalization phenomenon, which started with financial liberalization in developed countries in the 1970s, was expanded in the 1980s and 90s by developing countries. This globalization process, which started with financial liberalization, made the countries more affected with each other.

Countries implemented closed-economy policies in the pre-1970's, followed by trade and financial liberalizations have facilitated international capital flow.The international capital, which the countries see as an additional source for faster development, has caused the rapid spread of shocks in the countries which are integrated with the phenomenon of globalization.

FDI are investments made by investors outside the borders of a country by establishing facilities such as factories, opening branches, real estate or buying an existing company in whole or in part.It is required to draw from the developed countries to the developing countries with the idea of developing the economy such as employment, technology transfer, integration into international markets, development of competitive environment and training of qualified labor force in the medium and long-term. It is considered as an important condition for success in effective investment, job creation, high wages and technology transfer. Therefore, many countries

\footnotetext{
1 Res. Asst., Trakya University, mikailpehlivan@trakya.edu.tr
} 
follow many incentive policies to attract FDI (Artige \& Nicolini, 2006: 1). In this context, Turkey as one of the developing countries has made many arrangements until today.

Therefore, this study estimated the economic factors that are determinants of FDI inflows to Turkey and these factors' relationship with FDI inflows have been disclosed.

\section{The Determinants of Foreign Direct Investments: Theoretical Framework}

In the literature, the variables used to explain FDI are quite a lot.The variables used to explain the FDI theories in empirical studies are generally based on the United Nations report "World Investment Report 1998: Trends and Determinants". In this part, the relations of the variables to be used in the analysis with FDI will be explained.

The first is the size of the market. Market size is the driver for FDI inflows. At this point, in order to measure market size in econometric studies, Gross Domestic Product (GDP) or GDP per capita is taken as data. It is stated that firms will move towards the markets of large and developing countries with the idea that their investments will be higher and thus make more profit (Jordaan, 2004: 40).

The second is the trade openness, which is expressed as the ratio of the sum of exports and imports to GDP. This data shows the speed or potential of the goods and services produced by investors to deliver to the world markets. The degree of trade openness of countries also affects markets in the country. Providing raw materials or intermediate goods in a country that follows limited trade policies will result in higher costs than countries that follow free trade policies (Kravis \& Lipsey, 1982: 216). In this framework, the market size and the fewer trade limitations will create an attractive production and marketing area for the FDI (Culem, 1988: 900; Edwards, 1990: 10).

The third is the exchange rate. In FDI theories, exchange rate is considered as an indicator that measures competitiveness. This is because the exchange rate affects the competition in the market with income and cost effects. Income effect is positive on FDI but on the other side, the cost effect has a negative impact on FDI. Therefore, the effect of exchange rates on FDI will be determined by the advantages of income and cost effects on each other (Chakrabarti, 2001: 163).

The fourth is labor cost. It is generally accepted that the low labor cost is effective on FDI. Firstly, the attractive conditions that will be generated by a reduction in production costs; secondly, high productivity is taken into consideration besides cheap labor. Low labor costs and high quality labor force are important factors for FDI (Candemir, 2009: 670; Shamsuddin, 1994: 44).

The fifth and last variable isenvironmental taxes. Leonard (1988) explains the impact of environmental regulations on FDI with two hypotheses: "Pollution haven" and "industrial flight". The pollution haven hypothesis explains the FDI flowing towards developing countries through fewer environmental regulations. In the industrial flight hypothesis, investments that flow to other countries are explained due to the tightening of environmental regulations in developed countries (Hansen, 1998: 9-10). 


\section{The Determinants of Foreign Direct Investments in Turkey}

In this study, the effects of growth, trade openness, exchange rate, labor cost and environmental taxes on FDI are analyzed using the ARDL.

\subsection{Model, Data and Method}

In the analysis, the functional form of the model created to identify the determinants of FDI in Turkey is as follows:

$\mathrm{FDI}_{t}=f(G D P, O P E N, R E E R, L C, E T X)$

The definitions of the variables included in this function are as follows: FDI=Foreign Direct Investments, GDP=Gross Domestic Product, OPEN=Trade Openness [(Total Import + Total Exports / GDP], REER=Real Effective Exchange Rate representing the exchange rate, LC=Labor Cost, ETX=Environmental Taxes.The logarithmic states of the FDI, GDP, REER, LC, ETX variables were used. Accordingly, the model to be estimated is formed as follows:

$L F D I=\theta_{0}+\theta_{1} \cdot L G D P+\theta_{2} \cdot$ OPEN $+\theta_{3} \cdot L R E E R+\theta_{4} \cdot L L C+\theta_{5} \cdot L E T X+\varepsilon_{t}$

In the study, the quarterly time series of the 2007-2018 related to these variables were analyzed and the data was taken from The Central Bank of the Turkish Republic, Ministry of Finance and OECD databases.

\subsection{Methodology}

\subsubsection{Unit Root Tests}

In the study, firstly stationary analyzes of the time series in the model were performed. A stationary time series is one whose statistical properties such as mean, variance, autocorrelation, etc. are all constant over time. Otherwise, there is a possibility of false regression problem in analysis with non-stationary series (Gujarati \& Porter, 2012: 740, 762). Augmented Dickey-Fuller (ADF) and Phillips-Perron (PP) unit root tests were used to determine the stability of the series.

\subsubsection{Autoregressive Distributed Lag}

The idea of cointegration was first introduced by Granger (1981) and Granger and Weiss (1983). Then it was developed by Engle and Granger (1987). The difference between ARDL bound test and these methods used in cointegration analysis is that: According to these cointegration tests, series should be stationary at the same level. However, in the ARDL bound test, the existence of a cointegration relationship between series can be investigated regardless of whether the series are I (0) or I (1). Another advantage of this model is that it allows analysis to be carried out with a small number of observations (Narayan \& Narayan, 2004: 101-102). 


\section{Findings and Evaluation}

First, the variances of the series were stabilized by taking the logarithm of the non-proportional series before the unit root tests were performed. According to the ADF unit root test results, except for OPEN and LLC variables, the entire series were stationary (I (0)); OPEN and LLC variables became stationary (I (1)) after the first differences were obtained. According to the PP unit root test, except for the LLC variable, the entire series is stationary (I (0)); the LLC variable became stationary (I (0)) after the first difference. Information on ADF and PP unit root tests is shown in Table 1.

Table 1. Unit Root Tests Results

\begin{tabular}{|l|l|c|c|c|}
\hline \multirow{2}{*}{ Variables } & \multirow{2}{*}{ ADF } & \multicolumn{3}{c|}{ Critical Values } \\
\cline { 3 - 5 } & & $\mathbf{1 \%}$ & $\mathbf{5 \%}$ & $\mathbf{1 0 \%}$ \\
\hline LFDI & $-4,3^{*}(0)$ & $-3,58$ & $-2,92$ & $-2,60$ \\
\hline LGDP & $-4,47^{*}(5)$ & $-4,21$ & $-3,52$ & $-3,19$ \\
\hline OPEN & $-2,33(5)$ & $-3,61$ & $-2,93$ & $-2,60$ \\
\hline LREER & $-4,12^{* *}(1)$ & $-4,18$ & $-3,51$ & $-3,18$ \\
\hline LLC & $-2,30(2)$ & $-4,19$ & $-3,52$ & $-3,19$ \\
\hline LETX & $-1,85^{* * *}(5)$ & $-2,62$ & $-1,94$ & $-1,61$ \\
\hline$\Delta$ OPEN & $-3,46^{*}(5)$ & $-2,62$ & $-1,94$ & $-1,61$ \\
\hline$\Delta$ LLC & $-4,76^{*}(1)$ & $-3,59$ & $-2,93$ & $-2,60$ \\
\hline \multirow{2}{*}{ Variables } & \multirow{2}{*}{ PP } & \multicolumn{3}{|c|}{ Critical Values } \\
\cline { 3 - 6 } & & $\mathbf{1} \%$ & $\mathbf{5} \%$ & $\mathbf{1 0 \%}$ \\
\hline LFDI & $-4,34^{*}(1)$ & $-3,58$ & $-2,92$ & $-2,60$ \\
\hline LGDP & $-5,29^{*}(3)$ & $-4,18$ & $-3,51$ & $-3,18$ \\
\hline OPEN & $-3,41^{* *}(4)$ & $-3,58$ & $-2,92$ & $-2,60$ \\
\hline LREER & $-3,31^{* * *}(3)$ & $-4,18$ & $-3,51$ & $-3,18$ \\
\hline LLC & $-2,49(6)$ & $-4,18$ & $-3,51$ & $-3,18$ \\
\hline LETX & $-4,35^{*}(3)$ & $-4,18$ & $-3,51$ & $-3,18$ \\
\hline$\Delta$ OPEN & $-8,5^{*}(18)$ & $-2,61$ & $-1,94$ & $-1,61$ \\
\hline$\Delta$ LLC & $-7,11^{*}(5)$ & $-3,59$ & $-2,93$ & $-2,60$ \\
\hline
\end{tabular}

Note: $\left({ }^{* *}\right)$ ) $10 \%$ significance level, $\left({ }^{* *}\right) 5 \%$ significance level and $\left({ }^{*}\right) 1 \%$ significance level is statistically significant

After the stationary tests of the series, the existence of the cointegration relationship between the series will be tested with ARDL model and the long and short-term dynamics will be examined according to the results obtained. The model to be used in the study of cointegration relationship was formed according to Akaike Information Criterion (AIC) by taking the maximum lag length 4 .

Table 2. Bound Test Results

\begin{tabular}{c|cc|cc|cc}
\hline \multirow{2}{*}{ F-statistic } & \multicolumn{5}{|c}{ Critical Values } \\
\cline { 2 - 7 } & \multicolumn{2}{|c|}{$\mathbf{1 \%}$} & \multicolumn{2}{|c}{$\mathbf{5 \%}$} & \multicolumn{2}{c}{$\mathbf{1 0 \%}$} \\
\cline { 2 - 7 } & $\mathbf{I}(\mathbf{0})$ & $\mathbf{I}(\mathbf{1})$ & $\mathrm{I}(\mathbf{0})$ & $\mathbf{I}(\mathbf{1})$ & $\mathbf{I}(\mathbf{0})$ & $\mathrm{I}(\mathbf{1})$ \\
\hline $\mathbf{1 6 , 5 6}$ & 3,93 & 5,23 & 3,12 & 4,25 & 2,75 & 3,79 \\
\hline
\end{tabular}


According to the results of ARDL boundary test F-statistic, which is calculated as 16,56, is higher than the upper limit of $1 \%$ significant level shows that there is a cointegration relationship between the variables. In this direction, the long-term relationship between the variables was determined with the help of ARDL model. The long-term results are shown in Table 3.

Table 3. Long-term Coefficients

\begin{tabular}{lccc}
\hline & Coefficient & Standard Error & t-statistic \\
\hline LGDP & 1.551645 & 0.984200 & 1.576554 \\
\hline LLC & $-8.003936^{*}$ & 2.190119 & -3.654568 \\
\hline LREER & $6.325385^{*}$ & 1.890867 & 3.345230 \\
\hline LETX & 0.159693 & 0.409999 & 0.389495 \\
\hline OPEN & -2.212067 & 2.356868 & -0.938562 \\
\hline $\boldsymbol{c}$ & -21.342575 & 26.777334 & -0.797039 \\
\hline @trend & 0.158979 & 0.061061 & 2.603606 \\
\hline
\end{tabular}

Note: $\left({ }^{*}\right)$ shows that statistically significant at $\% 1$ significance level

According to ARDL model long-term estimation results; it was determined that labor cost and real effective exchange rate variables had a statistically significant effect on FDI. The long-term results obtained can be summarized as follows:

There is a negative correlation between LC and FDI at $1 \%$ significance level. $1 \%$ increase in LC reduces $\mathrm{FDI}$ by $8 \%$.

There is a positive correlation between REER and FDI at $1 \%$ significance level. $1 \%$ increase in REER increases FDI by $6 \%$.

In the following part of the analysis, the error correction model based on ARDL model was estimated and short-term dynamics were examined. 
Table 4. Error Correction Model Results

\begin{tabular}{|c|c|c|c|}
\hline & Coefficient & Standard Error & t-statistic \\
\hline$\Delta L F D I_{t-1}$ & -0.100372 & 0.128423 & -0.781576 \\
\hline$\Delta L F D I_{t-2}$ & $-0.377135^{* *}$ & 0.143140 & -2.634732 \\
\hline$\Delta L G D P_{t}$ & 0.264308 & 0.688033 & 0.384150 \\
\hline$\Delta L L C_{t}$ & -0.604074 & 1.498654 & -0.403078 \\
\hline$\Delta L R E E R_{t}$ & $-3.347884 * *$ & 1.177509 & -2.843192 \\
\hline$\Delta L R E E R_{t-1}$ & 0.108537 & 1.474148 & 0.073627 \\
\hline$\triangle L R E E R_{t-2}$ & $-4.905053^{*}$ & 1.216694 & -4.031459 \\
\hline$\Delta L E T X_{t}$ & -0.355894 & 0.219472 & -1.621592 \\
\hline$\Delta L E T X_{t-1}$ & 0.160546 & 0.199873 & 0.803239 \\
\hline$\Delta L E T X_{t-2}$ & -0.094753 & 0.196770 & -0.481541 \\
\hline$\Delta L E T X_{t-3}$ & $-0.926497^{*}$ & 0.199818 & -4.636698 \\
\hline$\triangle L O P E N_{t}$ & 0.320714 & 1.406388 & 0.228041 \\
\hline$\triangle L O P E N_{t-1}$ & 2.280529 & 1.643611 & 1.387511 \\
\hline$\triangle L O P E N_{t-2}$ & -2.006482 & 1.549991 & -1.294512 \\
\hline$\triangle L O P E N_{t-3}$ & $2.794801^{* * *}$ & 1.362087 & 2.051852 \\
\hline$\Delta @$ trend $_{t}$ & $0.130413^{*}$ & 0.042401 & 3.075671 \\
\hline$e^{e c m_{t-1}}$ & $-0.820315^{*}$ & 0.123509 & -6.641726 \\
\hline
\end{tabular}

Note: $\left({ }^{* *}\right) 10 \%$ significance level, $\left({ }^{* *}\right) 5 \%$ significance level and $(*) 1 \%$ significance level is statistically significant.

The fact that ecm $\mathrm{t}_{\mathrm{t}-1}$ term, which indicates that whether the deviations in the short-term will be corrected in the long-term, is considered to be 0 to $-1(-0,82)$ in order to be statistically significant. In other words, it is estimated that the short-term deviations will be balanced in

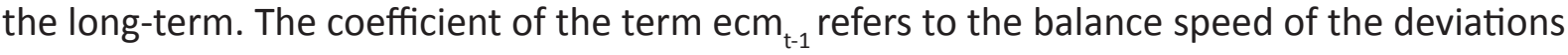
in the short-term.

\section{Conclusion}

According to the findings, it was found that REER and LC were statistically significant on FDI, it was observed that there was a positive relationship with REER and a negative relationship with LC in the long-term. It can be said that the weight of the use of imported inputs in the production of FDI is high because FDI inflows to Turkey negatively impacted by exchange rate increases (in other words, positively impacted by REER increases). According to this result, it can be said that FDI inflows to the country are not export-oriented but oriented towards the national market. Therefore, the decrease in the exchange rate may increase the supply of goods and services to the national market by reducing the imported input costs. 
LC is an important factor especially for FDI who want to do business in the manufacturing sector. At this point, the labor cost is repulsive; labor productivity is an attractive factor.According to the findings, there is a negative correlation between LC and FDI at $1 \%$ significance level. $1 \%$ increase in $\mathrm{LC}$ reduces FDI by $8 \%$.

In this context, public spending in Turkey can be channelled to well-structured education and health services in order to remove the negative effects of labor costs on FDI. Improving human capital can also help attract technology-intensive FDI to the country.

\section{References}

\section{Journals/Periodicals;}

Candemir, A. (2009). “Doğrudan Yabancı Sermaye Yatrımlarını Etkileyen Faktörler”, Ege Akademik Bakış Dergisi, 9(2), ss. 659-675.

Chakrabarti, A. (2001). "The Determinants of Foreign Direct Investments: Sensitivity Analyses of Cross-Country Regressions", Kyklos, 54(1), pp. 89-114.

Culem, C. G. (1988). "The Locational Determinants of Direct Investments Among Industrialized Countries", European Economic Review, 32(4), pp. 885-904.

Edwards, S. (1990). Capital Flows, Foreign Direct Investment, and Debt-Equity Swaps in Developing Countries, NBER Working Paper No. 3497, pp. 1-35.

Kravis, I. B. \& Lipsey, R. E. (1982). "The Location of Overseas Production and Production for Export by US Multinational Firms", Journal of International Economics, 12(3-4), pp. 201-223.

Narayan, S. \& Narayan, P. K. (2004). “Determinants of Demand for Fiji's Exports: An Empirical Investigation", The Developing Economies, 42(1), pp. 95-112.

Shamsuddin, A. F. (1994). "Economic Determinants of Foreign Direct Investment in Less Developed Countries", The Pakistan Development Review, 33(1), pp. 41-51.

\section{Books;}

Gujarati, N. D. \& Porter, C. D. (2012). Temel Ekonometri, 1. Basım, (Çev.) Ümit Ş. \& Gülay G. Ş., İstanbul, Literatür Yayıncılık.

Hansen, M. W. (1998). Economic Theories of Transnational Corporations, Environment and Development, Copenhagen, Copenhagen Business School.

\section{Thesis:}

Jordaan, J. C. (2004). Foreign Direct Investment and Neighbouring Influences, (PhD Economics), Pretoria, University of Pretoria. 